\title{
The Gospel's Light and the Inner Illumination of Understanding in 2 Corinthians 4:3-6. Its Influence upon the Patristic Thought
}

\section{Ioan MIHOC*}

Abstract: Light and darkness are used in the Bible as metaphors for good and evil. In 2 Cor. 4:3-6 Saint Paul uses light as a metaphor for the "Good News of the glory of Christ" (4:4), as well as for the inner act of conversion (4:6). Actually his words may be taken in reference with his Damascus road encounter with Christ Himself within a bright light (Acts 9:1-5; 26:16-18) and with regard to general Christian conversion, because he clearly is talking about an interior, spiritual illumination of Christ. Here Paul explains why some people cannot understand the Gospel. Satan prevents people from seeing the light of Christ's glory, because Satan is the prince of darkness. But God can and will bring light into the minds of people. The same God Who created light in the beginning has filled Paul's heart with "the light of the knowledge of the glory of God in the face of Jesus Christ." In other words, the same God Who created the miracle of light also creates the miracle of faith. Before conversion on the Damascus road, Paul himself had been blind to the Gospel. As one turns to the Lord, there is the inner illumination of understanding that foretastes the ultimate glory of God. In this paper we scrutinize the influence of this Pauline passage on the patristic interpretation about

* Associate professor $\mathrm{PhD}$, Didactic Orthodox Theology Department of Caransebeș, "Eftimie Murgu" University of Reșiţa, email: ioanmihoc@gmail.com. 
the Gospel's light, on the one hand, and the inner light as illumination through the work of the Holy Spirit, on the other hand.

Keywords: Gospel, glory, veil, illumination, conversion, uncreated spiritual light.

\section{Introduction}

In 2 Cor 3:1-4:6, Apostle Paul reacts against those who were discrediting his work and glorifying the mystery of the apostolate, showing that it is superior to the role performed by Moses (3:1-18). With this awareness he has the audacity to preach the Gospel's light and truth (4:1-6). ${ }^{1}$ However, he notes that, as a veil (kalumma) was preventing Israel to see the divine glory (3:13-16), so the glory of the Gospel is hidden (kaluptō) for all those who perish, those with their minds (noèma) blinded by the god of this age (4:3-4). Throughout this entire section, St. Paul uses the image of vision / sight $(3: 7,13 ; 4: 4$; see also $4: 18)$, but the truth of the Gospel can be mastered only by listening to the preached word. The blinded eyes are not those that do not see, but the blinded minds are those who do not understand (4:4). On the road to Damascus, Paul saw Jesus resurrected, but he needed God's message through Ananias, to straighten his life and to place him on the path of sacrificial ministry and love. ${ }^{2}$ Only after

${ }^{1} 4: 1-6$ is a passage reminiscent of the passage from $3: 1-6$, both in theme and in tone. The Gospel is an illuminating force (Rom 1:16) because it reveals the glory of Christ which reflects (3:18) God's glory (4:6) and is in contrast to Moses (3:7), the mediator of the Old Covenant (3:14). St. Paul emphasizes that not he matters, but Christ Who is working in him (4:5-15; 13:3). In 4:1, Paul and his collaborators are those who have "the ministry" of the New Covenant (3:6-9), and therefore they do not "lose hope" (and $4: 16$; cf. 3:4,12) regardless of the personal price paid for it (4:7-16) (Craig S. Keener, 1-2 Corinthians, The New Cambridge Bible Commentary, Cambridge University Press, 2005, p. 172).

${ }^{2}$ Acts 9:10-19; see also his vision and the Lord's command in 22:17-21. 
the blinding veil has been removed, he could see the glory of God on the Christ's face. Thus, he came to preach Jesus Christ as being the Lord and to show that the Apostles are "your servants, for Jesus" (2 Cor 4:5). ${ }^{3}$

The language of Paul in 4:4 and 4:6 underlines the contrast between spiritual blindness and enlightenment: ${ }^{4}$

\begin{tabular}{|l|l|}
\hline $\mathbf{4 , 4}$ & $\mathbf{4 , 6}$ \\
\hline $\begin{array}{l}\text { god } \\
\text { of this age } \\
\text { blinded } \\
\text { the unbelievers' minds } \\
\text { not to illuminate them } \\
\text { the Gospel's light }\end{array}$ & $\begin{array}{l}\text { God } \\
\text { Who shone light from the dark } \\
\text { shone } \\
\text { to Christ's glory } \\
\text { in our hearts } \\
\text { to (pros) } \\
\text { the light of knowledge } \\
\text { to God's glory } \\
\text { on Christ's face }\end{array}$ \\
\hline
\end{tabular}

The glory that Paul discovers and the world rejects it is Christ, the image of God (4:4): "whose minds the god of this age has blinded, who do not believe, lest the light of the gospel of the glory of Christ, who is the image of God, should shine on them". The phrase "the god of this age" appears in the New Testament only here and most of the commentators understand it in reference to Satan. Paul describes Satan as the main enemy that blinds the minds of unbelievers (cf. 2:11). The image has already been presented in the Jewish apocalyptic describing the Prince of light and the angel of darkness leading different realms and being involved in a mortal fight. ${ }^{5}$ The

${ }^{3}$ Only here Paul speaks of himself as the "servant" of his converts (David E. Garland, 2 Corinthians, The New American Commentary, vol. 29, B \& H Publishing Group, Nashville, Tennessee, 1999, p. 214).

${ }^{4}$ Craig S. Keener, 1-2 Corinthians, p. 173.

${ }^{5}$ David E. Garland, 2 Corinthians, p. 211. 
blindness of the unbelievers' mind is intentionally contrasted with "the light of the Gospel". Here, as in 2 Cor 4:6, the word used for "light" (photismos) is not merely the commonly used noun, but a secondary derived form from the verb "to give light" or "to illuminate". The blinded one cannot see even the sunshine of the midday sun. The eye of the soul must first receive the light. Those spiritually blinded are prevented from seeing the glory of Christ, Who is the image of God. As God's image, Christ the Saviour casts clarity upon the hazy notions regarding the "immortal and invisible" God "dwelling in unapproachable light" (1 Tim 1:17; 6:16). The Pauline phrase "the light of the gospel of the glory of Christ" shows that the Gospel is not only imbued with glory, but it partakes from Christ's glory, which it has as its theme and subject.

On the other hand, the Apostle emphasizes that God, Who has revealed glory to creation, has revealed now His full glory in Christ (4:6). By using the text found in Isaiah 9:1-2 to express the idea regarding God creating the light (Gen 1:3), Paul can also evoke his mission among the pagans in 4:6. Surely we can see in 4:6 an allusion to the episode concerning Paul's own conversion. According to Luke, Paul himself was blinded and then iluminated (Acts 9:8 and the coresponding places). In the fifth apologetical sermon in Acts $26,{ }^{6}$ we have an insistence on the heavenly light theme that shone more than the midday sun. It was not a dream, but an experience lived by all that were present there. This light

${ }^{6}$ The sermon in front of King Agrippa and the procurator Festus (Acts 26:123) is the fifth apologetic sermon on behalf of Paul, according to The Act of the Apostles book, and it is uttered before a Herodian King and a Roman procurator. The five apologetic sermons were held before: 1. the Jewish People (Acts 21:37-40: Acts 22:1-21); 2. the Sanhedrin (23:1-11); 3. Felix (24:10-21); 4. Festus (Acts 25:8-12) and 5. King Agrippa II (Constantin Preda, Propovăduirea apostolică. Structuri retorice în Faptele Apostolilor, publ. by IBM of BOR, Bucharest, 2005, p. 288). 
was not seen only by Paul (cf. Acts 9:4; 22:7), but it has also enveloped all of them who were accompanying him.

Significantly is the fact that it does not cause his blindness (cf. Acts 9:8; 22:11), but it constitutes the object of the vision. The Gospel's Light becomes evident within the mission entrusted to him by the Risen Saviour, for it refers to "the eyes' opening" (v. 18) and the testimony of what he saw (v. 16); he also was sent to turn them from darkness to light (v. 18) and to proclaim the light (v. 23). St. Paul has been enveloped by light and has seen the light of God's brilliance in order to be able to proclaim it. ${ }^{7} \mathrm{He}$ has received then Christ and His Gospel as the light of his whole life. ${ }^{8}$

In 2 Cor 4:6 the Apostle establishes a correlation between the primordial light and light as impartment of knowing Christ within the believers' hearts (souls). "For it is God Who commanded light to shine out of darkness, who has shone in our hearts" (4:6). The free quotation from Gen 1:3, "God Who said, Let light shine out of darkness," identifies the Creator Who remains in action in order to illuminate (Is 9:2). The individual

${ }^{7}$ Seeing the light corresponds to the revelation of the Risen Jesus Christ, as it emerges from the use of the verb ophthe. St. Luke usually uses this verb to describe the Saviour's Paschal appearances to Simon Peter (Lk 23.34), to the apostles (Acts 13:31) and to St. Paul, on the road to Damascus (cf. Acts 9:17; 26:16). The light that has enveloped St. Paul is shown as coming "from heaven" (ouranothen, cf. v. 13 and 19; Acts 9:3; 22:6). Unlike the first two stories regarding St. Paul's "conversion" (Acts 9:4 and Acts 22:7), now "all of them" fall to the ground, but only St. Paul has heard the voice of the Risen Jesus (Constantin Preda, Propovăduirea apostolică, p. 300301).

${ }^{8}$ The image of the light that shines reminds most of the commentators about the account of Paul's own conversion experience. In Acts it is described as a light from heaven (Acts 9:3; 22:6,11;26:13) and relates itself to glory (Acts 22:11; doxa, brightness). However, The Acts do not present this event as an inner illumination, but as an external reality. Paul directly states in 2 Cor 4:6 that the external reality has become an internal reality (David E. Garland, 2 Corinthians, p. 216-217). 
regeneration or the conversion is a work of God as supernatural and full of power as the world's creation (Gen 1:3). In context there is directly mentioned the conversion through which is acquired the light of understanding the Gospel: "Nevertheless, when one turns to the Lord, the veil is taken away" (2 Cor 3:16) and, therefore, the Apostle wants to share that light with others. Within the physical creation, God spoke directly, but in the spiritual creation of the new life, He speaks, usually, in an indirect manner, through His servants, of whom the Apostle himself is part of. However, the Word of God is the one who creates new life ( 2 Cor 5:17), the Apostle being only the bearer of Christ's light.

In 4.6b, the contrast with Moses (3:7 and the following) is done on purpose: to shine the knowledge of God's glory, on the face of Christ. ${ }^{9}$ In the Old Testament, two theophanies were accompanied by a bright light which no man could look at: the Lord's appearing in the burning bush, on Mount Horeb (Ex 3:6) and in receiving the Law, on Sinai (Ex 19:21). On leaving the cloud where he met God, Moses was wearing on his face the light from God's face, and thus, he had to cover his face with a veil in order to be seen by the Israelites (Ex 34:33; 2 Cor 3:13). On the other hand, St. Paul says that "until today, when Moses is read, a veil lies upon the heart" of those who did not believe in Christ, which means that they had not received "the Gospel's light" (2 Cor $3: 14-15 ; 4: 4)$. Now, in the new law of the grace, Paul wants to say that, the light of Christ's Gospel shines upon all men, and the "veil" does not lie on the Gospel as it was on Moses' face, but upon the "unbelievers' blinded minds" (2 Cor 4:4).

9 Jerome Murphy-O'Connor, "The Second Epistle to the Corinthians", in Raymond E. Brown, J. A. Fitzmyer and R. E. Murphy, Introducere și comentariu la Sfânta Scriptură, vol. VII, Literatura paulină, translated by Dumitru Groşan, Galaxia Gutenberg Publ. House, 2008, p. 161-162. 
Simeon the Metaphrastes, in Paraphrase to Macarius the Egyptian, refers extensively to the Pauline context that interests us, showing that the brightness of the divine light can be perceived by "every believing soul" through the Holy Spirit. St. Paul, says, it gives the example of the Holy Spirit's glory which was illuminating Moses' face wanting to highlight the possibility that, for the worthy in the Gospel's perfect faith, the Holy Spirit's imperishable and immortal glory to shine within the immortal man's inner inside.

"The Divine Apostle Paul has showed that Christianity's perfect mystery becomes experienced by every faithful soul in a cleaner and clear way, through God's work. And this is the brightness of the heavenly light revealed and powered by the Holy Spirit... He called what was committed then evanescent, for that the glory of the light enveloped the mortal body of Moses. And he adds: Having therefore such hope, we make use of great boldness (1 Cor 3:12). And a little further on he has showed that the Spirit's imperishable and immortal glory within discovery shines now in the immortal and imperishable eyes in the man's immortal inner side of the worthy. For say, But we all, with the face unveiled, beholding as in a mirror the glory of the Lord, are being transformed into the same image from glory to glory, just as by the Spirit of the Lord (2 Cor 3:18). With the face unveiled, the soul, i.e.: and when someone comes back to the Lord, his veil is taken away; and the Lord is the Spirit. Therefore he has showed, therefore clearly, that a dark veil was placed over the soul. And it could propagate itself through mankind after the fall of Adam. Now, however, we believe that through the Spirit's illumination this veil is removed from the truly faithful and worthy souls. For this reason Christ coming took place. And God has condescended that the truly faithful to reach such measures of holiness". ${ }^{10}$

10 Simeon Metrafrastul, „Parafraza în 150 de capete la cele cincizeci de Cuvinte ale Sfântului Macarie Egipteanul, Despre libertatea minţii, 137138", Filocalia, vol. 5, translation, introduction and notes by Fr. Prof. Dumitru Stăniloae, BOR's EIBM, Bucharest, 1976, p. 378-379. 
St. Gregory of Nyssa shows that "Christ is the true light unapproachable (1 Tim 6:16) to the lie". "By understanding this, he says further on, we understand at the same time that our life it must also be illuminated by the rays of the true Father. These rays, rays of the Sun of righteousness (Mal 3:20), are the virtues, ${ }^{11}$ that spring from here for our enlightenment. Through them, we can cast off the work of darkness (Rom 13:12) and walk properly, as in the day (Rom 13:13). Also through them we can leave aside all the hidden things of shame (2 Cor 4:2) and do everything in broad daylight, such as ourselves to be light and to be able to illuminate others through our work (cf. Mt 5:15-16), just as light". ${ }^{12}$ St. Gregory conceives man's original condition as being characterized by light. And the redemption process unfolds itself within the deifying union which is also conceived in the terms of light. Human nature was created so as to see and to participate in that light which is God. Participation in / and seeing the divine light is in some sense an epistemological meeting. ${ }^{13}$

${ }^{11}$ St. John Chrysostom shows too that virtues make the one performing them "brighter than the sun" and the sin "sinks" him in darkness and in the swamp of evil (St. John Chrysostom, Homily 28 at II Corinthians, PG 61. col. 50-51).

${ }^{12}$ Sf. Gregory of Nyssa, "Despre desăvârșire, către monahul Olimpiu”, translated by Olimp Căciulă, in Scrieri, partea a doua, PSB, vol. 30, translated and notes by Teodor Bodogae, BOR's EIBM, Bucharest, 1998, p. 462.

${ }^{13}$ Martin Laird, Gregory of Nyssa and the Grasp of Faith. Union, Knowledge and Divine Presence, Oxford Early Christian Studies, Oxford University Press, 2007, p. 182. For St. Gregory of Nyssa, Paul is a symbol of faith. Paul's encounter with the Word is described by him in terms of the divine dwelling; St. Gregory also develops the dynamics between apophasislogophasis largely with the aid of three texts from 2 Corinthians: 12:4; 13:3 and 2:15. The dwelling of Christ which Paul talks about (2 Cor 13:3) and Paul who brings "the good scent of Christ" (2 Cor 2:15) represents the logophatic correlative of the apophatic experience in 2 Cor 12:4 (Ibid., p. 170). St. Gregory speaks often of union through light deification. In Canticum Canticorum in his commentary, Gregory recalls Moses' meeting 


\section{The Gospel's Light (2 Cor 4:4)}

In connection with this verse, the Church Fathers stress that: 1. through faith man has access to the light of truth of Christ's Gospel 2. Christ is the heavenly Father's light and 3. we are called to get the brightness of Christ's glory: Didymus the Blind ${ }^{14}$ shows that he who has overcome the world through his faith has his eyes luminous: "Every unbeliever is of this world. None of those who have overcome it and made themselves worthy of the next world are blinded in his understanding, because his eyes were enlightened". ${ }^{15}$

Theodoret of Cyrus insists upon the fact that the truth will be evident in eschaton: "Paul says that unbelief is limited to this world, as in the next world the truth will be obvious to all."16 Clement of Alexandria refers himself to our call to resemble ourselves with Christ. "Our pedagogue, oh children, resembles his Father, Whose Son He is. He is sinless, blameless ... pure God in human form, fulfilling His Father's will. He is God the Word, Who is in the Father's bosom and also at His right side, and even in the God's being. He is the unblemished image" (cf.

with God. First, God showed Himself to Moses through light (dia photos), then He spoke to Moses from a cloud (dia nephelēs), for ultimately Moses to see God in the dark (en gnophō) (Ibid., p. 176-178). On numerous occasions in De Vita Moysis and In Canticum Canticorum Gregory stresses that the light which dissipates the darkness is in a certain sense an epistemological light. In connection with the burning bush theophany, he emphasizes that the truth shines (epilampsei) upon us and illuminates (periaygazousa) the eyes of the soul (Ibid., p. 179).

${ }^{14}$ Alexandrian exegete who was much influenced by Origen and admired by Jerome.

${ }^{15}$ Pauline comment from the Greek Church, NTA15:24, Cf. Thomas C. Oden, general editor \& Gerald Bray, edited by, 1-2 Corinthians, Ancient Christian Commentary on Scripture, New Testament, VII, Rotledge, Taylor \& Francis Group, New York, London, 2012, p. 228.

${ }^{16}$ Comment on the Second Letter to the Corinthians 308, Migne PG 82:399. 
2 Cor 4:4). To the question "What does God's face resembles to?" the Blessed Jerome replied: "Of course, with His face, because, for as the Apostle says, the Father's image is the Son (2 Cor 4:4). Therefore, may He shine upon us with His face, which it means, to shine His image, the Son, upon us so that $\mathrm{He}$ Himself may shine upon us, as the Father's light is the Son's light. The one who sees the Father, sees also the Son, and he who sees the Son, sees also the Father. Where there is no difference between glory and glory, there the glory is one and the same (The $6^{\text {th }}$ Homily to Ps 66-67). ${ }^{17}$

Secondly, within the patristic literature there stood out two answers diametrically opposed to the question "Who is the god of this world, who has blinded the unbelievers?" Some early commentators, combating the dualists, believed that Paul had referred to God. God is the only God, of this age and the one to come, they were saying. Tertullian, combating Marcion, claimed that Paul refers to God that blinds the minds of the unbelievers. ${ }^{18}$ And St. John Chrysostom believes that "The God of this world does mean neither the devil, no other creator, as the Manicheans say, but it refers to the God of the universe who has blinded the minds of the unbelievers of this world. In the world to come there will not be unbelievers, but only in this one". ${ }^{19}$

Others, like most of the modern commentators, see here a reference to the devil. For example, Pelagius believed that "the god of this world can be understood as being the devil, on the grounds that he claimed to rule over the unbelievers. Or, taking into account the attacks of the heretics, he can be understood in the sense that God has blinded the minds of the unbelievers

${ }^{17}$ Thomas C. Oden, Gerald Bray, 1-2 Corinthians, p. 228-229.

${ }^{18}$ Against Marcion 5.1 (Marcion has used this Pauline text in order to justify his ideas about an inferior creative God and a supreme Saving God); also see Hilary, Chrysostom, Augustine.

${ }^{19}$ Chrysostom, Hom. Cor. 8:2. 
because of their unbelief", ${ }^{20}$

The Jewish texts use similar expressions for God (Jub. 25:23), but in John's Gospel a similar language is used with regard to the devil (Jn 12:31; 14:30; 16:11). Also Paul's own way of speaking proves to be decisive: elsewhere, he speaks of the non-believers" false "god" (Phil 3:19: "the belly is their god"). God brings light, but Satan, darkness and spiritual blindness (also cf. 2 Cor 6:14-15: "Do not be unequally yoked together with unbelievers. For what fellowship has righteousness with lawlessness? And what communion has light with darkness? And what accord has Christ with Belial? Or what part has a believer with an unbeliever?"). ${ }^{21}$

\section{God has shone in our hearts ( 2 Cor $4: 6)$}

In connection with this verse, the Church Fathers highlight various aspects: receiving the hypostatical light; the superiority of the new creation in Christ; to shine with the divine light in the darkness of our hearts; the break of the divine wisdom through the Spirit's glowing stance; about the Holy Spirit's fire which accomplishes in the believers Christ's "conception" "in a sympathetic manner".

Simeon the Metaphrastes refers himself to 2 Corinthians 4:6, arguing that through the Spirit's illumination there is received the hypostatic light within the souls, as Paul received it on the road to Damascus:

"This glow of the Spirit, he says, is not only a kind of discovery of meanings and an enlightenment of the grace, as it has been said, but a safe and relentless illumination of the hypostatical light within the

${ }^{20}$ Commentary on the Second Epistle to the Corinthians 4, Migne PL 30: 781A-B.

${ }^{21}$ Craig S. Keener, 1-2 Corinthians, p. 173. 
souls... (2 Cor 4:6). And the light about which it is said that has shone in blessed Paul's path (Acts 9:3), through which he has also been taken up to the third heaven and heard unspeakable mysteries (2 Cor $12: 2,4$ ), was not an illumination through meanings or knowledge, but a hypostatic illumination within the soul on behalf of the good Spirit's power, Whose overwhelming brilliance not being able to endure it, the eyes of the body turned blind. Through it there is revealed all the knowledge and God becomes truly known revealing Himself to the worthy and loved soul". ${ }^{22}$

Chrysostom emphasizes the superiority of the renewed creation in Christ: "Do you see how Paul shows Moses' glory shining with more intensity to those who want to see it? It shines in our hearts, he says, just as it shone on Moses' face (Is 34:29$35)$. First, he reminds them of what was done in the beginning of creation (Gen 1:3) and then he shows them that this renewed creation is superior". 23

Theodoret of Cyrus talks about the glow with the divine light: "Since the divine nature is invisible and always remains so, it can be seen as it is in Jesus Christ's humanity which shines with divine light and irradiates outwards its rays". ${ }^{24}$

${ }^{22}$ Simeon the Metrafrast, " 150 Heads Paraphrase to St. Macarius of Egypt's 50 Words, About Mind's Freedom, 138-139”, Filocalia, vol. 5, p. 378-380.

${ }^{23}$ Homilies to the Epistles of Paul to the Corinthians 8:3.

${ }^{24}$ Cf. Thomas C. Oden and Gerald Bray, ed., 1-2 Corinthians, p. 230. In exegesis to the kenotic hymn in Philip from 2.6 to 11, Theodore underlines the Son's consubstantiality with the Father. St. Paul, he shows, does not say about the Word that He would have become God's image, but "being in God's image". The same ontological type of argument is used also in the Christological hymn from Col 1:15-20 (Cf. Constantin Crețu, "Fericitul Teodoret al Cirului, tâlcuitor al Epistolelor pauline. Studiu introductiv", in Fericitul Teodoret al Cirului, Tâlcuire la Epistolele Sfântului Apostol Pavel, vol. I, trans. by Iulia Cărare and Mircea Ștefan, publ. by Doxologia, Iassy, 2015, p. 21-22). Regarding Theodore's Christology, see also Paul B. Clayton, jr., The Christology of Theodoret of Cyrus. Antiochene 
St. Isaac of Nineveh (the Syrian) refers to "resurrection" and to the "emergence of the divine wisdom through the mystical brilliance of the Gospel's light": "Saying the Apostle: God, Who has commanded the light to shine out of darkness, He Himself has shone in our hearts (2 Cor 4:6), has showed the resurrection of the soul, the coming out of the old state. This we must understand. That is the emergence of the new man who has nothing of the old man, as it is said: I will give you a new heart and put a new spirit within you (Ezek 36:26). For then Christ's image appears into us through the Spirit of wisdom and of revelation of His knowledge". 25

St. Ambrose emphasizes that here there is a reference to the Spirit's brilliance: "Who is thus the One Who has shone in order for us to be able to know God within Jesus Christ's image? For he has said: God has shone (2 Cor 4:6), so that the glory of God to be known in Jesus Christ's image. How can we believe that anyone but the Spirit was the One Who has made Himself known? Or who but the Spirit could be the One to Whom is attributed the power of God? For those who exclude the Spirit must introduce another to receive, with the Father and the Son, the glory of the Godhead" (The Holy Spirit 3.12.86,88). ${ }^{26}$

Christology from the Council of Ephesus (431) to the Council of Chalcedon (451), Oxford Unuiversity Press, 2007, p. 179-206.

25 St. Isaac the Syrian, "Cuvinte despre nevoință", Philocalia, vol. 10, Humanitas Pub. House, 2008, p. 394. Commenting on this isaachian text, Father Stăniloae shows that "God is for us above light, He is the apophatic (unspeakable) darkness; but when He wants to get into communication with us, from this darkness belonging to Him light springs out. And thereby He resurrects our soul. Living close to God is the new life, which is also light" (Philocalia, vol. 10, p. 394, n. 647).

${ }^{26}$ Cf. Thomas C. Oden and Gerald Bray, ed., 1-2 Corinthians, p. 230-231. 
Sahdona ${ }^{27}$ speaks of the Holy Spirit's fire: "For that reason we should worship and glorify Him Who has lifted our dust to such a state, always remember the holiness of the One Who has mixed our spirit with His Spirit and has mixed in our bodies the gift of His grace, light the fire of the Holy Spirit in us. For He hath shined in our hearts (2 Cor 4:6) which had been submerged in darkness (Book of Perfection). ${ }^{28}$

The pious hermit Isaiah, in his work entitled Twenty-nine words, quotes 2 Cor $4: 7$, "But we have this treasure in earthen vessels ..." and Col 3:15, "And let the peace of God rule in your hearts" after which he states: "This means that God's Spirit dwells in you (Rom 8:11). And thus, from the darkness shone the light in your hearts to the brightness of the glory of God (2 Cor 4:6)". In his commentary, Father Dumitru Stăniloae explains that "the Spirit makes the light of knowledge to shine out of darkness. By ourselves we are darkness. But there is in us a thirst for light and a capacity to make us bearers of God's light, brought into us on behalf of the Holy Spirit." 29

St. Symeon the New Theologian, in The First Moral Discourse, shows that the Word Himself "begets" in believers:

"As God, the Father's Word, has entered into the womb of the Virgin, thus the Word is in us like a seed ... Therefore we beget Him not in

${ }^{27}$ Sahdona, a Syriac writer, known also as Martyrius, the Greek rendition of his name, was, for a short period of time, between $635-640$, bishop of Beth Garma. The Book of Perfection, his most important work, is a masterpiece of Syriac's monastic literature.

${ }^{28}$ Cf. Thomas C. Oden and Gerald Bray, ed., 1-2 Corinthians, p. 231.

${ }^{29}$ Filocalia, vol 12, publ. by Harisma, Bucharest, 1991, p. 149. Father Dumitru Stăniloae shows that "through the word spoken by the divine Word comes within us the very power of His person, which shapes us into His image. There is here a big difference between Orthodox and Protestants. They separate the spoken or written word of God, from the Word of God as a person and from his power" (Filocalia, vol. 6, 1977, p. 156, n. 281). 
bodily form, as the Virgin and the Theotokos has begotten Him, but comprehensively and existentially. And we have in our hearts the very One Whom the Virgin Mary has begotten, as the divine Paul says: God, who commanded light to shine out of darkness, who has shone in our hearts the enlightenment of the knowledge of His Son (2 Cor 4:6). It's like saying: He Himself shone entirely in an existential image into us. And this is the meaning of what he said, he showed it in the following, saying: And we have this treasure in earthen vessels (2 Cor 4:7), calling the Holy Spirit as treasure". ${ }^{30}$

Hesychius of Sinai refers to the prayer of Jesus as a concrete way of enlightening the mind and the heart:

"Truly happy is the one who has stuck in his thought the Jesus' prayer and cries incessantly for Him within his heart... And when the visions of the passions have been scattered, by Jesus Christ, the sun of righteousness, usually there are born within the heart stellar and bright meanings from its entire lightened sky by Jesus Christ ( 2 Cor 4:6). The one who deals with the commitment has as protection his or her heart, in time of prayer, the knowledge of the sensitive things, which he or she cannot lift it away because of the affection for them. Only the contemplative, being autonomous of them, can see, sideways, face unveiled, God's glory (2 Cor 3:18)". ${ }^{31}$

Basing on this Pauline verse, the Patriarch Callistus refers in a comparative manner to the two "preaching", stressing that the new law overwhelms through its gifts those that were only a "shadow" in comparison with the Gospel's truth:

"In that (old law) it is said that: God has said: Let there be light (Gen 1:3); in this: God Who commanded: light to shine out of darkness, has shone in our hearts (2 Cor 4:6). Thus the one who heeds ... to both

${ }^{30}$ St. Symeon the New Theologian, ,Întâia cuvântare morală”, Filocalia, vol. 6, p. 157.

${ }^{31}$ Hesychius of Sinai, "Despre trezvie şi virtute, suta a doua, 94.95”, Filocalia, vol. 4, p. 91. 
preaching, will clearly understand how much our good things surpass and overcome those of the old law and will say that those are a shadow and image next to our truth, or Christ's. And will praise and glorify God's grace and care, Who from shadow to image lifts our nature being to the mercy above being of the goodness above this world in Jesus Christ, our Lord". ${ }^{32}$

The glow of the unspoken things within the hearts of the faithful means training for seeing things beyond the natural limit, as Callistus shows us in a prayer:

"For, as you are true God, You truly are also light, as John gives testimony. Therefore those who have taken of Thy fullness release unvoiced cries, You the unpronounceable One, openly, that You are God, He Who commanded light to shine out of darkness, Who has shone in our hearts (2 Cor 4:6). And You illuminate and makes to obviously shine the ones beyond words, thus to prepare us to see the supernatural, beyond this world of grace and truth, above the heavens, and be merry". 33

The Patriarch Callistus presents both the mind's enlightening work from outside through the light of the Gospel (cf. 2 Cor 4:4), or of the Holy Scriptures, and the fact that God Himself communicates Himself as light within the hearts of the believers (4:6):

"It's really a wonderful thing that the faithful heart bears within itself the holy ray of the Most High God Who is above all. For it is a sweet,

${ }^{32}$ Callistus the Patriarch, "Capete despre rugăciune, 63", Filocalia, vol. 8, publ. by EIBM of BOR, Bucharest, 1979, p. 354. "It should have been that us who ... bear inscribed into our hearts, in an unspoken way, the new law (2 Cor 3:2-3), brighter than a candlestick, and are guided by the good and righteous Spirit... to live like the angels and not needing to be taught by someone, to know the Lord" (Callistus and Ignatius Xanthopol, "Cele 100 de capete, 1", Filocalia, vol. 8, p. 17; see also p. 21).

${ }^{33}$ Calist the Patriarh, "Capete despre rugăciune, 63”, Filocalia, vol. 8, p. 356-357. 
helpful and wonderful thing, and loving of people that God makes the mind to illuminate itself externally, through the Holy Scriptures (cf. 2 Cor 4:4). But to give Himself, in truth and in fact, as light to the believer, and this within the heart's innermost quarter (2 Cor 4:6), not outwardly, and forever, not in a passing stance, surpasses obviously even the miracle above all understanding. ${ }^{34}$ God who said light to shine out of darkness ( 2 Cor 4:6), brilliantly shines in the hearts of the faithful, says Callistus the Patriarch, showing that it refers to God's love (which) has spilled in their hearts through the Holy Spirit given them (Rom 5,5)". ${ }^{35}$

Callistus and Ignatius bring into attention 2 Peter 1:19, the nearest New-Testamentary text to 2 Cor $4: 4,6$, showing that being "the light of the world" means to walk in the light of Christ:

"(The perfect man) sees itself as in a mirror and also differentiate those travelling with him, as it has been said, You do well to heed as a light that shines in a dark place, until the day dawns and the morning star rises in your hearts (2 Peter 1:19)... About them has even been written: You are the light of the world (Mt 5:14), as also the all divine Paul says: God who commanded light to shine out of darkness, who has shone in our hearts to give the light of the knowledge of the glory of God in the face of Jesus Christ (2 Cor 4:6). But also the blessed David says: Lord, lift up the light of Your countenance upon us (Ps 4:6); and In Your light we see light (Ps 35:9). And the Lord says, I am the light of the world. He who follows Me shall not walk in darkness, but have the light of life (Jn 8:12)". ${ }^{36}$

${ }^{34}$ Callistus the Patriarch, "Capete despre rugăciune, 67", p. 360-361.

35 Callistus the Patriarch, "Capete despre rugăciune, 72", p. 363. Note of Fr. Stăniloae: "Light and love is the same thing, as hate and darkness are too. God is light, is an opening, because He is love (note 684, p. 363). God sends the Spirit of his Son into their hearts and He cries out: Abba, Father" (Gal 4:6).

${ }^{36}$ Callistus and Ignatius Xanthopol, "Cele 100 de capete, 42", p. 100-101. And elsewhere, they refer themselves to God's gracious work through which the hearts of the "true faithful" become illuminated: "In fact, through this, as through an ever burning and all illuminating candlestick, the truly faithful are led and look to those beyond the senses and become clear as to someone who 


\section{Contemplating the light of Christ}

The allegations St. Paul's regarding the Gospel's light and Christ's light that shines in the hearts of the faithful have had a strong echo within the patristic literature. The mystical view of the light of Christ is a clear and constant teaching of the Orthodox Church. Also the hesychastic experience of meeting with Christ in the light, through the pure prayer of the heart, is a central teaching of the Fathers of the Church. To name just a few examples:

St. Gregory of Nazianzus explains that "God unites Himself with gods and is revealed by them; and this is the illumination of the hypostasis of the Holy Spirit within the heart". "It is born (...) of the aforementioned pure and the prayer totally contained within the heart" ${ }^{\prime 38}$ as point out Callistus and Ignatius. They speak of the illumination of the heart by "sticking to God", urging thus: "tend with all your strength to stick to God and He will lighten your heart regarding the spiritual work" ${ }^{39}$ For someone to be part

is pure in his heart (Mt 5:8), the heavenly gate of all the beings and high status, alike to the angels. And thus dawns upon them again, as from a disc of the sun, the possible to think, to discern, to see through, to foresee, and the rest alike. Simply speaking, through this dawns upon them all the appearance and revelation of the mysteries and fill themselves with the divine and the supernatural power in the Spirit" (Callistus and Ignatius Xanthopol, "Cele 100 de capete, 38" Filocalia, vol. 8, p. 214).

37 St. Gregory of Nazianzus, Cuv. 34.13; PG 36,253 A; "Enypostatos ellampsis, it's an illumination that springs from the very hypostasis of the Holy Spirit dwelt in the heart. It is felt as light of His Person, or it enlightens Him as a Person that has entered in relation with man, as a person" (Pr. D. Stăniloae Filocalia 8, p. 94, n. 188 a).

${ }^{38}$ Callistus and Ignatius, Filocalia, vol. 8, p. 94. Father Stăniloae shows that "the illumination of the Spirit is born out of the pure prayer within the heart, in the depths of our transparent being, which vibrates of the communication that occurs between him and the Holy Spirit" ( Fr. D. Stăniloae Filocalia, vol. 8, p. 94, n. 188b).

${ }^{39}$ Callistus and Ignatius Xanthopol, "Cele 100 de capete, 38" Filocalia, vol. 8, p. 94-95. 
of "the happy light of divinity", Hesychius of Sinai shows that it is important to cleanse the mind of thoughts and fantasies:

„Because all thought enters the heart through imaginating [visions of] any sensible things, the happy light of divinity will illuminate the mind when it will rest for all and will leave any form that comes from it. For that glow shows itself to the clean mind when all thoughts disappear [images]". 40

Simeon the Pious, in the Capetele morale, refers himself to the prayer at the end of which shines an ineffable light:

„If while you are praying ... any light shine or something else happens, do not be troubled. But persist harder within the prayer. For arises a devilish disorder or any fear or any exit from oneself (ecstasy), as weakening to leave the prayer and, having reached such a habbit, to make you his prey. But if in doing the prayer, any light impossible to be interpreted shines to you, and your soul becomes filled by an unspeakable joy and by the desire for the highest and your tears begin to run accompanied by repentance, then know that this is a Divine visit and a Divine help". ${ }^{41}$

${ }^{40}$ Hesychius of Sinai, "Despre trezvie și virtute" Filocalia, vol. 4, p. 63. Receiving Christ through the Holy Eucharist is the illumination of our life, provided that we guard the mind and the heart, through the prayer of Jesus' name: "if after [receiving the most pure Communion] with zeal we will guard our mind and sit at the gate of our heart, when we become again worthy of them, the Divine Body will illuminate even more our mind and make it like a star" (Ibid p. 66). "As the one gazing at the Sun is impossible not to fill his or her eyes with the abundant light, in the same manner the one who pays attention to scrutinize the sky of the heart, cannot fail to illuminate himself or herself" (Ibid, p. 68; see also p. 84.86).

41 "Capetele morale ale lui Simeon Evlaviosul, 31", Filocalia, vol. 6, 1977, p. 111. Elsewhere, inquiring how someone has experienced at his ordination the gracious work of the Holy Spirit, Simeon recorded thus: "Asked by me, how he has seen Him (the Holy Spirit) then (at his ordination) and under which image, he said: "simple and imageless, but as light" ("Capetele morale ale lui Simeon Evlaviosul", p. 118). It is about a common idea for 
St. Symeon the New Theologian show that "all the saints, those of yesteryear and those from now, seeing with spiritual eyes, do not look at a form, or an image, or a reproduction, but a light without form, as they too are light from the Spirit's light". ${ }^{42}$ He refers also to the eschatological brightness of Christ in the souls of the righteous:

"And when the saints' consciousness books will be opened - take
heed! - Christ will shine, God, the One hidden now within them as
He ever shone before the beginnings of times, from the Father. And
the saints will be like the Most High (Is 14:14). How do we know
this? Listen to the Saviour Himself, saying this: Then the righteous
will shine like the sun (Mt 13:14). And what other image or sun it is
this, if not the One about Which I have spoken, the only One called
by Himself The Sun of righteousness (Mal 3:20), Who alone will
rise and shine in the righteous?" 43

Speaking from his spiritual experience, St. Symeon the New Theologian recalls that "God is light and seeing Him is like a light. Thus in seeing the light is given to us the first acknowledge that there is a God ... When someone sees Him uncovered, sees a light ... A sweet light..."44

Summing up the tradition before him, St. Gregory Palama teaches that "the subsistent light that the saints see it in a spiritual form is subsistent in hypostasis (fos enypostatos), as they themselves confess, as one that exists and is not just something

the three: Simeon the Pious, St. Symeon the New Theologian and Nikita Stethatos (Fr. D. Stăniloae, n. 246, p. 118).

${ }^{42}$ St. Symeon the New Theologian, "Întâia cuvântare morală", Filocalia, vol.

6, 1977, p. 134.

${ }^{43}$ St. Symeon the New Theologian, "Întâia cuvântare morală", p. 174.

${ }^{44}$ St. Symeon the New Theologian, "A cincea cuvântare morală”, p. 193-194.

For other references regarding the theology of light at St. Simeon see:

Hilarion Alfeyev St. Symeon the New theologian and Orthodox Tradition, Oxford Scholarship Online, 2011, p. 226 et. u. 
symbolic, as are the ghosts fabricated according to the occurring circumstances. They know from experience that it is a divine and immaterial light and grace, a light seen in an unseen way and understood in an unknown way". 45

St. Seraphim of Sarov highlights that only "under the pretext of teaching, of Enlightenment, we have entered into such darkness of ignorance that today we find unthinkable all those about which the ancients had notions so clear as to speak among themselves about God's appearances to people like things known to all and not at all unusual". ${ }^{46}$

From the patristic references presented above emerges the fact that the Church Fathers supports the posibility of seeing God in the very concrete way as is the one of the hypostatical light, through which they understand that it refers to the contemplation of Christ as light and within light, as the apostles saw Him on the Mount of Transfiguration. In this sense, Paul's own experience is revealing on the road to Damascus, but also the call that he has received to bring people from darkness to the light of the Gospel. If the old law was written on tablets of stone $(3: 3,6)$, the Gospel's light shines in human's hearts through the Holy Spirit, of those who receive ,the knowledge of the glory of God, in the face of Christ" (4:6).

${ }^{45}$ Sf. Gregory Palama, "Cuvânt pentru cei ce se liniștesc cu evlavie. Despre sfânta lumină", Filocalia, vol. 7, publ. by Humanitas, Bucharest, 1999, p. 276.

${ }^{46}$ Cf. Paul Evdokimov, Prezența Duhului Sfânt în Tradiția Ortodoxă, trans. by Vasile Răducă, publ. by Anastasia, 1995, p. 32-33. 